\title{
Attitudes towards the Use of ICT in Costa Rican University Students: The Influence of Sex, Academic Performance, and Training in Technology
}

\author{
José-Antonio García-Martínez ${ }^{1,2, * \mathbb{D}}$, Eduardo-José Fuentes-Abeledo ${ }^{3}$ and Eduardo-Rafael Rodríguez-Machado ${ }^{2}$ \\ 1 Research Center in Teaching and Education, Nacional University, Heredia 86300, Costa Rica \\ 2 Department of Pedagogy and Didactics, University of A Coruña, 15071 A Coruña, Spain; \\ e.rodriguez.machado@udc.es \\ 3 Department of Pedagogy and Didactics, University of Santiago de Compostela, \\ 15782 Santiago de Compostela, Spain; eduardo.fuentes@usc.es \\ * Correspondence: jose.garcia.martinez@una.cr
}

check for updates

Citation: García-Martínez, J.-A.; Fuentes-Abeledo, E.-J.; Rodríguez-

Machado, E.-R. Attitudes towards the Use of ICT in Costa Rican University Students: The Influence of Sex, Academic Performance, and Training in Technology. Sustainability 2021, 13, 282. https://doi.org/10.3390/ su13010282

Received: 23 November 2020 Accepted: 27 December 2020 Published: 30 December 2020

Publisher's Note: MDPI stays neutral with regard to jurisdictional clai$\mathrm{ms}$ in published maps and institutional affiliations.

Copyright: (C) 2020 by the authors. Licensee MDPI, Basel, Switzerland. This article is an open access article distributed under the terms and conditions of the Creative Commons Attribution (CC BY) license (https:// creativecommons.org/licenses/by/ $4.0 /)$.

\begin{abstract}
Information and communication technologies (ICT) are being used more and more as part of teaching processes in both formal and informal settings. In this regard, it is important to understand university students' attitudes towards using ICT as they will shortly form part of the productive sector of society. The aim of this study was to analyze student attitudes during their final years pursuing various degrees at a university in Costa Rica. We used a non-experimental transactional design and probabilistic sampling that involved 1187 students. We used a questionnaire containing a Likert-type scales to measure attitudes, which was structured according to affective, cognitive, and behavioral components. The results showed positive attitudes in general, with higher scores in the cognitive and behavioral components, and moderate scores in the affective component. In addition, we found differences in attitudes according to sex, prior training in technology, and academic performance.
\end{abstract}

Keywords: information and communication technologies (ICT); attituded towards ICT; educational technology; lifelong learning; self-regulated learning

\section{Introduction}

In recent years, governments in many countries and influential international organizations (i.e., the Organization for Economic Cooperation and Development (OECD) and the United Nations Educational, Scientific, and Cultural Organization (UNESCO) have shown an interest in information and communication technologies (ICT) as promotors of change in general education, particularly vis-à-vis the university setting. The expectation is that the inclusion of ICT will bring with it innovative processes that will have an impact on the economy, production, and all sectors of society.

Universities are formal settings that favor the acquisition and reinforcement of ICT skills and competencies [1]. This perspective has two aspects: on the one hand, it requires the university student to be the protagonist of their own training, supporting the idea of self-directed learning [2] and lifelong learning [3], which does not solely depend on a formal process or a particular educational stage. On the other hand, the competencies developed via these processes will be extrapolated into both work and personal areas [4].

What is available in terms of current technology nowadays provides a broad range of free resources, especially via web 2.0, which makes various activities that promote learning possible. However, there needs to be critical use of ICT to make the most of the possibilities both in formal and informal contexts [5]. Considering the huge amount of information online, search tools and information management tools have become one of the most important, widely-used tools for students [6,7]. Another group of tools includes 
those used to create content in multiple formats, although studies in this regard indicate that they are less widely used [8,9]. Lastly, but no less important, there are social tools that allow information to be shared and interaction between users [10,11].

Although there are many advantages of including ICT in learning environments, it is also important to remember that using ICT is not without various obstacles [12]. Connection difficulties and limited access to devices are thought to be two of the main reasons for the digital divide between different socioeconomic sections of the population [13]. Similarly, the rapid appearance of different resources produces obstacles to keeping up to date [14]. In addition, not having skills or training in technology becomes a problem that can lead to having lower technological competencies [15]. Against this backdrop, having positive attitudes towards the inclusion of ICT is necessary for the technological changes facing society [16], and makes up part of the complex framework of personal learning environments [13].

The attitudes of university students towards ICT has been widely studied in recent years [17] but it is still an important topic of study given how widespread it is in formal and particularly non-formal settings [18], even more so in the frameworks of emergent learning theories such as connectivism [19], educational approaches such as Personal Learning Environments (PLE) [10], and the peak of learning processes such as self-directed learning [20] and lifelong learning [3]. Although the contribution of ICT to education and, therefore, to the development of human capital is clear [20], attitude and technology as a pair still needs research to provide suitable responses to the current dynamic context of the information and knowledge society [21], particularly vis-à-vis university students who will soon be making up some of the productive part of the population.

\section{Attitudes towards ICT}

The concept of attitude has been a cause for debate. For this study, we defined attitudes as the prior disposition to an action [22]. Attitudes are not innate; they are learned or acquired via socialization and vary between groups and individuals depending on different cultural factors, and as a result of each subjects' various experiences [23]. In this regard, attitudes towards ICT use may be affected by the rapid proliferation of these tools, their use in all walks of life, and by the social interactions they result in. In order to make measuring easy, researching attitudes via quantitative studies is usually structured in various components [21,23] with what is called the ABC model [24]. For this study, we made reference to the work [22] which, in response to the aforementioned model, differentiates three components in the study of attitudes: (a) cognitive, referring to a person's knowledge, thoughts, information, and beliefs ("I think it is positive to progressively include ICT in my studies"); (b) affective, which responds to value, and feelings of pleasure or dislike ("I feel good using a methodology that includes ICT"); and (c) behavioral, which refers to actions and behavior in a situation ("the use of ICT helps me do my academic tasks better").

Nowadays, general technological resources and those particularly related to web 2.0 are associated with social communication [25], wherein content can be shared and interactions had through comments on wikis, blogs, and social networks, etc. In this regard, studies have examined the technology acceptance model (TAM) more deeply [26], concluding that attitudes are one of the more significant determining factors of behavioral intentions, in addition to perceived usefulness and ease of use [27], with a positive influence on attitudes towards technology use [28]. In other words, attitudes towards ICT can predict future use of technology, and are a key factor in the TAM model, which can influence student behavior for the use of certain technological resources [29].

\section{University Students' Attitudes towards ICT}

At the international level, previous studies have shown that university students generally exhibit positive attitudes towards ICT [16,30]. Other researchers have found similar results but warned of the need to consider whether effective use is being made of the technology [31]. Positive attitudes have also been found towards social tools [32]. 
Despite the encouraging results, many studies have noted moderate command, and little knowledge of ICT [6,9,33,34], as well as instrumental use [35].

Some studies have related the use of ICT with improvements in learning via creative activities [36] that lead to positive changes in student performance thanks to the effective use of technology [37]. In any case, they have shown how attitudes towards the use of ICT can influence the development of PLEs, which need the engagement of students in ecosystems that encourage lifelong learning [38]. Studies in this regard have recognized the importance of technology and digital skills in learning throughout life [39,40].

It has also been demonstrated, albeit in secondary school students, that some of the components of attitudes toward ICT, particularly interest, competence, and autonomy, are positively related to student academic success [41]. Studies have also compared attitudes towards ICT as a function of sex, although there is little agreement in the results. Some studies [42] found more positive attitudes in men in the cognitive and behavioral components, whereas other studies differ, finding higher, more significant scores from women $[23,43]$. In any case, it is important to look at this topic more deeply, and especially to consider specific aspects of the Costa Rican setting, where significant efforts are being made to encourage women to do technological and scientific courses, and to increase their employability in these sectors [44].

\section{Methodology}

The methodology for this study was carried out under a quantitative approach. We produced an ex post facto transactional design, bearing in mind that the variables were not manipulated, and data collection was carried out at a single timepoint [45].

\subsection{Objective}

With all of the above in mind, the general objective of this study was to examine the attitudes towards the use of ICT in final-year university students. To do that, we established the following specific objectives:

1. Identify the attitudes towards the use of ICT in this group of students on the basis of affective, cognitive, and behavioral components.

2. Determine whether sex, prior training in ICT, and academic performance are significantly influential variables in the attitudes towards the use of ICT.

\subsection{Population and Sample}

The population $(n=3165)$ comprised students in their final year of either bachelor's or licentiate degrees, at the National University (UNA) of Costa Rica.

The sample $(n=1187)$ was a stratified probabilistic analysis [45], with each faculty and facility considered a stratum. The sample size was defined using the calculation for finite [46]: error 3\%, 95\% confidence, and the expected $p$ value $(p=5 \%)$. In addition, we considered representativeness (Figure 1), and obtained data from a total of 51 courses from the seven knowledge areas of UNA.

The majority of the sample (64.1\%) were women and just over a third $(35.9 \%)$ were men. Ages ranged from 20 to 57 years old $(M=24 ; S D=4.18)$. In terms of academic performance, $30.0 \%$ had failed no subjects and had an average grade over $9,26.6 \%$ had never failed a subject but had an average grade below 9 , and $43.5 \%$ of the sample had failed at least one subject.

\subsection{Data Collection Instruments and Techniques}

To collect the data, we used a questionnaire [47] that was created and validated for this research. The instrument is structured in various blocks with closed, dichotomous, and multiple choice questions seeking personal data, academic data, data about access to and use of technological devices, and training in ICT. One of the blocks included the scale of attitudes towards the use of ICT with 24 items measuring the three components noted above (Table 1): cognitive (e.g., "I think it is positive to progressively include ICT in my 
studies"; affective (e.g., "I would love to study somewhere which has more technological resources"; and behavioral (e.g., "I think teachers should use ICT to facilitate their students' learning"). Each item was evaluated using a 5-point Likert-type scale (from 1, meaning completely disagree, to 5 , meaning completely agree). It is important to note that to produce the mean for the factors and the scale overall, we recoded the items written in a negative format (e.g., "ICT does not promote my active learning as a student"). Internal consistency was evaluated via Cronbach's alpha (Table 1), which produced a coefficient of $\alpha=0.90$ for the total scale, $\alpha=0.77$ in the cognitive component, $\alpha=0.74$ in the affective component, and $\alpha=0.76$ in the behavioral component, comparable to results in other similar studies [22]. In all cases, we found coefficients above the 0.70 recommended by theory.

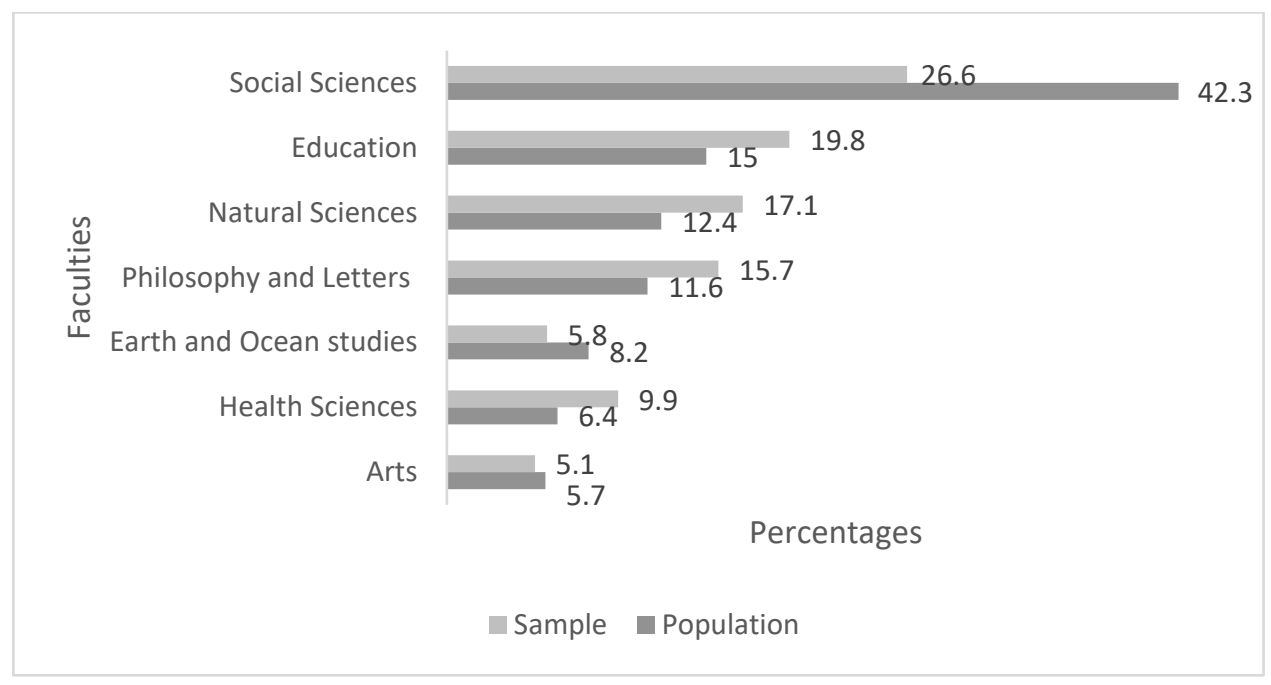

Figure 1. Population and sample percentages by knowledge area. Source: Authors' own work based on the data from the National University (UNA) Registration Department.

Table 1. Correlation matrix and descriptive statistics for the overall scale and components.

\begin{tabular}{ccccccccc}
\hline & $\mathbf{1}$ & $\mathbf{2}$ & $\mathbf{3}$ & $\mathbf{4}$ & Alpha & M & SD & Items \\
\hline Cognitive (1) & $0.695^{* *}$ & $0.788^{* *}$ & $0.920^{* *}$ & 0.77 & 4.26 & 0.59 & $1,4,5,11,14,18,23$, and 24 \\
Affective (2) & & $0.776^{* *}$ & $0.817^{* *}$ & 0.74 & 3.83 & 0.53 & $6,7,8,10,13,15,19$, and 22 \\
Behavioral (3) & & & $0.921^{* *}$ & 0.76 & 4.14 & 0.61 & $2,3,9,12,16,17,20$, and 21 \\
Overall scale (4) & & & & 0.90 & 4.13 & 0.56 & From 1 to 24 \\
\hline
\end{tabular}

**. The correlation is significant at the level of 0.01 (bilateral).

\subsection{Procedure and Data Analysis}

Once the questionnaire was created, it was submitted for validation by 20 experts in higher education and research methodology. Following that, we performed a pilot study with a sample of 45 students with similar characteristics to the final sample. The questionnaire was applied in the classrooms, with prior coordination with the responsible parties in each faculty. When the instrument was introduced, the students were informed of the objective of the study, and the procedure for data treatment, along with how their data would be treated, and they were assured of the voluntary, anonymous, and confidential nature of the study.

We produced a database using SPSS v.21. Firstly, we performed descriptive tests of both position and dispersion to identify attitudes towards the use of ICT. We also performed a Pearson correlation test between the study variables. Subsequently, in pursuit of our second objective, we made comparisons between groups using MANOVA, ANOVA, and the Student's $t$ test. Before carrying out these parametric tests, we performed an analysis of normality using the Kolmogorov-Smirnov test for the different groups, as well 
as Levene's test of homogeneity of variance. In both cases, values of $p>0.05$ indicated that the assumptions needed for the tests noted above were met.

\section{Results}

\subsection{Descriptive Analysis of the Attitudes towards ICT Use Scale}

We first performed a Pearson correlation test between the overall scale and the components. The results (Table 1) show high, positive coefficients between 0.70 and 0.92 both between the components and the overall scale. We also obtained excellent reliability in the tests of internal consistency, all being above 0.7 . The highest scoring component was cognitive $(\mathrm{M}=4.26$; $\mathrm{SD}=0.59)$, followed by behavioral $(\mathrm{M}=4.14 ; \mathrm{SD}=0.61)$, and lastly, affective $(\mathrm{M}=3.83$; $\mathrm{SD}=0.53)$. The mean in the overall scale was $\mathrm{M}=4.13(\mathrm{SD}=0.56)$, indicating that, overall, the Costa Rican students had positive perceptions of the use of ICT.

We then extracted the statistics of central tendency and distribution for the items (Table 2) making up the scale. The mean scores ranged between a minimum of $1.72(\mathrm{SD}=1.02)$ for the item "It doesn't seem helpful to me to add ICT to the course", corresponding to the affective component, and a maximum of $4.65(\mathrm{SD}=0.67)$ for the item "I think that ICT is very important for learning nowadays", corresponding to the behavioral component. It is also worth noting that the items with the lowest mean scores were in the cognitive and behavioral components. In the former, this was the items: "The use of ICT doesn't allow students to have more significant learning" $(\mathrm{M}=1.75)$ and "I'm not interested in the possibilities of ICT in teaching" $(\mathrm{M}=1.75)$. In the behavioral component, the lowest scores were in the items: "Using ICT is irrelevant for learning" $(\mathrm{M}=1.87)$ and "ICT in classes is burdensome" $(\mathrm{M}=1.95)$.

In contrast, the highest mean scores were in the cognitive component ("I have to make an effort to keep up to date to make the most of the didactic opportunities of ICT", with a mean of 4.44, and "I think it is positive to progressively include ICT in my studies", with a mean of 4.53).

\subsection{Analysis of Differences in Attitudes According to the Variable Sex}

We began by testing both normality using the Kolmogorov-Smirnov test $(p>0.05)$ for both groups (men and women), and homogeneity of variance, using Levene's test ( $p$-value $=0.230)$. As both assumptions were met, we performed the Student's $t$ test. As Table 3 shows, women had higher means and there were significant differences between men and women in both attitudes towards the use of ICT and in its three components.

\subsection{Analysis of Differences in the Attitudes to ICT Scale According to the Variable Training in ICT}

We performed the same comparisons of means to identify differences according to the variable training in ICT. Prior to that, we confirmed normality via the KolmogorovSmirnov test, giving a non-significant ' $p$ ' value $(p>0.05)$. The data from the Student's $t$ test (Table 4) showed that students who had not had any type of ICT training scored higher in both the overall scale and in each of the components. Similarly, we noted differences between those who had received training at university $(\mathrm{M}=4.19 ; \mathrm{SD}=0.56)$ and those who had not had that training $(\mathrm{M}=4.09 ; \mathrm{SD}=0.56 ; \mathrm{t}(1182)=2.723, p=0.007)$. We also found differences in attitudes between those who had done a virtual course $(\mathrm{M}=4.23$; $\mathrm{SD}=0.58)$ and those who had not $(\mathrm{M}=4.11 ; \mathrm{SD}=0.56 ; \mathrm{t}(1182)=2.380, p=0.017)$. This confirms that there were differences in attitudes towards ICT depending on ICT training. 
Table 2. Descriptive statistics of the attitudes towards information and communication technologies (ICT) scale.

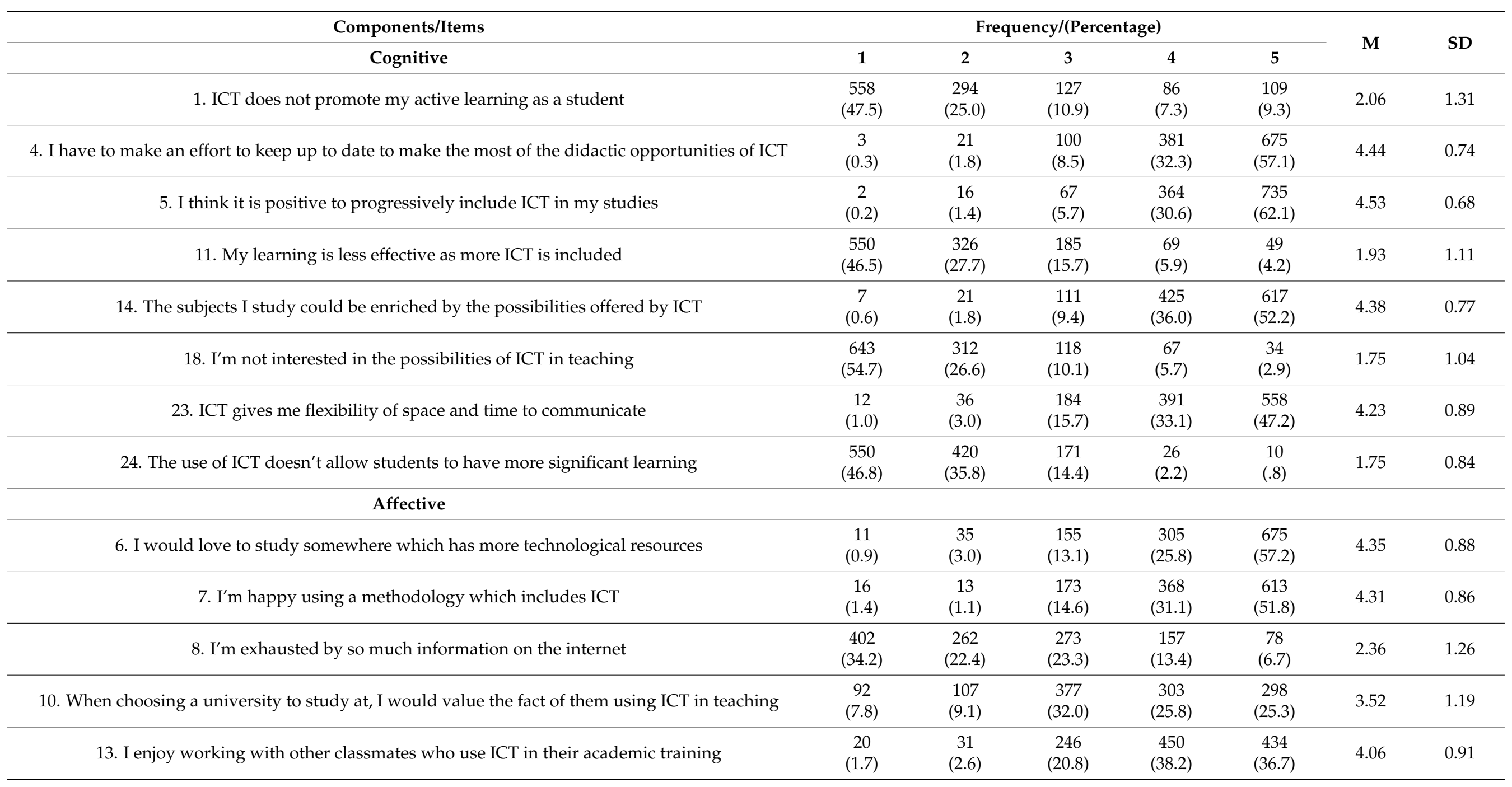


Table 2. Cont.

\begin{tabular}{|c|c|c|c|c|c|c|c|}
\hline \multirow{2}{*}{$\begin{array}{c}\text { Components/Items } \\
\text { Affective }\end{array}$} & \multicolumn{5}{|c|}{ Frequency/(Percentage) } & \multirow{2}{*}{$\mathbf{M}$} & \multirow{2}{*}{ SD } \\
\hline & 1 & 2 & 3 & 4 & 5 & & \\
\hline 15. It makes little sense that ICT is going to change education & $\begin{array}{c}528 \\
(44.8)\end{array}$ & $\begin{array}{c}325 \\
(27.6)\end{array}$ & $\begin{array}{c}175 \\
(14.8)\end{array}$ & $\begin{array}{c}100 \\
(8.5) \\
\end{array}$ & $\begin{array}{c}51 \\
(4.3) \\
\end{array}$ & 2.00 & 1.15 \\
\hline 19. It doesn't seem helpful to me to add ICT to the course & $\begin{array}{c}662 \\
(56.1)\end{array}$ & $\begin{array}{c}314 \\
(26.7)\end{array}$ & $\begin{array}{c}107 \\
(9.1)\end{array}$ & $\begin{array}{c}61 \\
(5.2)\end{array}$ & $\begin{array}{c}34 \\
(2.9)\end{array}$ & 1.72 & 1.02 \\
\hline 22. It concerns me that in the future, as a student, I will have to use ICT more & $\begin{array}{c}467 \\
(39.9)\end{array}$ & $\begin{array}{c}243 \\
(20.7)\end{array}$ & $\begin{array}{c}263 \\
(22.4)\end{array}$ & $\begin{array}{c}128 \\
(10.9)\end{array}$ & $\begin{array}{c}72 \\
(6.1) \\
\end{array}$ & 2.23 & 1.25 \\
\hline \multicolumn{8}{|l|}{ Behavioral } \\
\hline 2. I think teachers should use ICT to facilitate their students' learning & $\begin{array}{c}1 \\
(0.1) \\
\end{array}$ & $\begin{array}{c}12 \\
(1.0) \\
\end{array}$ & $\begin{array}{c}77 \\
(6.5) \\
\end{array}$ & $\begin{array}{c}301 \\
(25.4)\end{array}$ & $\begin{array}{c}793 \\
(67.0)\end{array}$ & 4.58 & 0.67 \\
\hline 3. I think that ICT is very important for learning nowadays & $\begin{array}{c}6 \\
(0.5)\end{array}$ & $\begin{array}{c}8 \\
(0.7)\end{array}$ & $\begin{array}{c}49 \\
(4.1)\end{array}$ & $\begin{array}{c}266 \\
(22.5)\end{array}$ & $\begin{array}{c}858 \\
(72.2)\end{array}$ & 4.65 & 0.64 \\
\hline 9. ICT in classes is burdensome & $\begin{array}{c}510 \\
(43.3)\end{array}$ & $\begin{array}{c}355 \\
(30.1)\end{array}$ & $\begin{array}{c}208 \\
(17.6)\end{array}$ & $\begin{array}{c}79 \\
(6.7)\end{array}$ & $\begin{array}{c}27 \\
(2.3)\end{array}$ & 1.95 & 1.04 \\
\hline 12. Using ICT is irrelevant for learning & $\begin{array}{c}590 \\
(50.3)\end{array}$ & $\begin{array}{c}307 \\
(26.2)\end{array}$ & $\begin{array}{c}174 \\
(14.8)\end{array}$ & $\begin{array}{c}64 \\
(5.5)\end{array}$ & $\begin{array}{c}38 \\
(3.2)\end{array}$ & 1.85 & 1.07 \\
\hline 16. ICT does not allow students to practice the acquisition of some basic intellectual skills & $\begin{array}{c}397 \\
(33.7)\end{array}$ & $\begin{array}{c}282 \\
(24.0)\end{array}$ & $\begin{array}{c}261 \\
(22.2)\end{array}$ & $\begin{array}{c}163 \\
(13.9)\end{array}$ & $\begin{array}{c}73 \\
(6.2)\end{array}$ & 2.35 & 1.25 \\
\hline 17. It should be a priority to improve current ICT infrastructures & $\begin{array}{c}53 \\
(4.5) \\
\end{array}$ & $\begin{array}{c}52 \\
(4.4) \\
\end{array}$ & $\begin{array}{c}266 \\
(22.6)\end{array}$ & $\begin{array}{c}428 \\
(36.3) \\
\end{array}$ & $\begin{array}{c}380 \\
(32.2)\end{array}$ & 3.87 & 1.05 \\
\hline 20. Using ICT will help me to do my academic tasks better & $\begin{array}{c}16 \\
(1.4)\end{array}$ & $\begin{array}{c}32 \\
(2.7)\end{array}$ & $\begin{array}{c}135 \\
(11.5)\end{array}$ & $\begin{array}{c}443 \\
(37.6)\end{array}$ & $\begin{array}{c}551 \\
(46.8)\end{array}$ & 4.26 & 0.86 \\
\hline 21. My learning as a student will not be improved by the use of ICT & $\begin{array}{c}514 \\
(43.6)\end{array}$ & $\begin{array}{c}288 \\
(24.5)\end{array}$ & $\begin{array}{c}188 \\
(16.0)\end{array}$ & $\begin{array}{c}106 \\
(9.0)\end{array}$ & $\begin{array}{c}81 \\
(6.9)\end{array}$ & 2.11 & 1.25 \\
\hline
\end{tabular}

Note: $n=1187$; response options 1 = "completely disagree"; 2 = "disagree"; 3 = "neither agree nor disagree"; 4 = "agree"; 5 = "completely agree"; $\mathrm{M}=$ mean; $\mathrm{SD}=$ standard deviation. 
Table 3. Results of the Student $t$ tests for the components of the attitudes to ICT scale in relation to the variable sex.

\begin{tabular}{|c|c|c|c|c|c|c|}
\hline \multirow{2}{*}{ Variable "Sex" } & \multicolumn{3}{|c|}{ Group Statistics } & \multicolumn{3}{|c|}{$T$ Test for the Equivalence of Means } \\
\hline & Sex & Mean & SD & $\mathbf{t}$ & df & Sig. (Bilateral) \\
\hline \multirow{2}{*}{ Attitudes } & M & 4.07 & 0.59 & \multirow{2}{*}{2.789} & \multirow{2}{*}{1180} & \multirow{2}{*}{0.005} \\
\hline & $\mathrm{F}$ & 4.17 & 0.54 & & & \\
\hline \multirow{2}{*}{ Cognitive } & M & 4.18 & 0.61 & \multirow{2}{*}{3.228} & \multirow{2}{*}{1180} & \multirow{2}{*}{0.001} \\
\hline & $\mathrm{F}$ & 4.30 & 0.57 & & & \\
\hline \multirow{2}{*}{ Affective } & M & 3.79 & 0.52 & \multirow{2}{*}{3.066} & \multirow{2}{*}{1180} & \multirow{2}{*}{0.004} \\
\hline & $\mathrm{F}$ & 3.85 & 0.52 & & & \\
\hline \multirow{2}{*}{ Behavioral } & M & 4.08 & 0.64 & \multirow{2}{*}{2.559} & \multirow{2}{*}{1180} & \multirow{2}{*}{0.011} \\
\hline & F & 4.17 & 0.58 & & & \\
\hline
\end{tabular}

Note: SD = standard deviation; $\mathrm{df}$ = degrees of freedom; $\mathrm{Sig}$ = significance.

Table 4. Group statistics and results of Student's $t$ tests of the attitudes towards ICT scale and its components according to the variable ICT training.

\begin{tabular}{|c|c|c|c|c|c|c|}
\hline \multirow{2}{*}{ Variable "ICT Training" } & \multicolumn{3}{|c|}{ Group Statistics } & \multicolumn{3}{|c|}{$t$ Test for the Equivalence of Means } \\
\hline & Training & Mean & SD & $\mathbf{t}$ & df & Sig. (Bilateral) \\
\hline \multirow{2}{*}{ Attitudes } & Yes & 4.15 & 0.56 & \multirow{2}{*}{2.407} & \multirow{2}{*}{1177} & \multirow{2}{*}{0.016} \\
\hline & No & 4.04 & 0.57 & & & \\
\hline \multirow{2}{*}{ Cognitive } & Yes & 4.28 & 0.58 & \multirow{2}{*}{2.361} & \multirow{2}{*}{1177} & \multirow{2}{*}{0.018} \\
\hline & No & 4.17 & 0.59 & & & \\
\hline \multirow{2}{*}{ Affective } & Yes & 3.85 & 0.52 & \multirow{2}{*}{3.066} & \multirow{2}{*}{1177} & \multirow{2}{*}{0.033} \\
\hline & No & 3.75 & 0.54 & & & \\
\hline \multirow{2}{*}{ Behavioral } & Yes & 4.16 & 0.60 & \multirow{2}{*}{2.559} & \multirow{2}{*}{1177} & \multirow{2}{*}{0.038} \\
\hline & No & 4.06 & 0.61 & & & \\
\hline
\end{tabular}

Note: SD = standard deviation; $\mathrm{df}$ = degrees of freedom; Sig = significance.

\subsection{Analysis of Differences in Attitudes towards ICT Depending on the Variable Academic Performance}

We performed a unidirectional multivariate analysis of variance between groups to examine the differences in academic performance (independent variable) in the attitudes towards ICT use, with the components of the latter being used as dependent variables. Before the MANOVA analysis for academic performance, we examined the equality of covariance using Box's M (Box's M = 103.4, F = 5.14, $p=0.000$ ), which showed that the supposition was not met. Because of that, we chose to use Pillai's Trace for the analysis of multivariate significance of main effects, following the recommendations from [48]. The MANOVA showed a significant main effect for academic performance, Pillai's Trace $=0.030$, $F(4,1169)=11.277, p=0.000, \eta 2=0.037$. Subsequent univariate ANOVA tests showed that students who reported not having failed any courses and whose grades were 9 or higher exhibited significantly higher values in attitudes towards ICT use $(F(2,1172)=20.98$, $p=0.000$ ) than either of those who had not failed any courses but had grades below 9 or those who had failed one or more courses.

\section{Discussion and Conclusions}

Our results were similar to findings from other studies [30,31], showing that final-year students at the National University of Costa Rica generally tended to have positive attitudes towards the use of ICT. This positive factor is the first step in facing the technological changes of current work-related demands [16]. Similarly, this favorable disposition makes it easier for students to add various tools to their PLEs $[9,10,34]$, which, if used effectively, 
may facilitate self-directed [2], lifelong, and 'life-wide' learning [3], something which is desirable if the learning process is not to be restricted to a formal institution or a specific stage of life [4].

If we look closely at the components proposed from the ABC model [22,24], it is clear that the cognitive component, an aspect related to students' thoughts and beliefs about ICT use, received the highest scores $(M=4.26)$. The behavioral component also scored highly $(\mathrm{M}=4.14)$, whereas the affective component had more moderate scores $(\mathrm{M}=3.83)$.

Universities can be agents of change by effectively incorporating ICT [5] in the teaching/learning process, strengthening the skills and competencies needed by these future professionals [1]. Developing better digital skills may promote lifelong learning [39,40].

We identified significant differences in the overall attitudes towards ICT use scale, and in the cognitive, affective, and behavioral components with respect to sex, women scoring higher than men. This finding is in line with findings from prior studies $[23,30,43]$, but differs from those that reported better attitudes in men [24]. This suggests that caution is warranted when interpreting this analysis, given the lack of consensus in previous studies. In addition, because we are dealing with attitudes, the results may be affected by the characteristic cultural aspects of each context [23].

In terms of prior ICT training, it is worth highlighting that a high proportion $(80.9 \%)$ of subjects reported having done ICT courses of different types. The results showed significant differences, with higher scores, both in the overall attitude scale and the components from students who had done prior ICT training. When evaluating this data, one should bear certain previous studies in mind, which indicated both moderate use and scant knowledge of ICT in university students [6,33]. On the other hand, one must also consider possible obstacles, such as the rapid appearance of resources, and the impossibility of keeping up with them [14], in order to assess how technology is valued. Training in ICT is vitally important, whether part of formal curricular activities in the different courses, or through informal training spaces. Making the most of the opportunities offered by both environments is key in the development and enrichment of personal learning environments [10] and avoiding a gap in future professionals' technical skills [15].

Finally, in agreement with [41], it is clear that there is a relationship between ICT and student academic performance. Students whose grades were 9 or over and who had not failed any subjects scored significantly higher in attitudes than those who had lower grades or who had failed a subject. Studies in this area indicate that effective ICT use can lead to increased academic performance [37] through innovative and creative learning strategies [36].

Understanding final-year university students' attitudes towards ICT use is essential, considering its impact in the educational and work environments. The continual development of PLEs is particularly important in this regard [10]. It is the user who is the protagonist of learning [2] in formal and particularly informal settings, developing life skills that can be transferred to social, academic, and work-related environments [3]. The positive attitudes students demonstrated towards ICT use may benefit aspects such as searching for and managing information, making best use of the different formats that are adapted to learning styles [6,7]. In addition, content creation develops creative skills [10] by making use of the potential of current web 2.0 resources that make content distribution quick and easy $[8,9]$. Lastly, and perhaps most importantly, the social component of PLEs $[11,25]$ allows communication and interaction, producing learning networks between users, and facilitating collaborative working, dialog, and critical analysis, among other types of skills that are needed in various areas of life [10].

Although our results demonstrate students' positive attitudes towards ICT, it is advisable that universities promote training and keeping up to date in technologies for all involved (students, teachers, admin and service staff), both in formal and non-formal settings which encourage self-directed, lifelong learning. In this regard, we suggest strategies and planning activities in which the usefulness of ICT can be seen, applying those which are easiest to use depending on the objectives, given the positive influence these factors exert on attitudes [28] and on the future use of certain resources [29]. The learning 
opportunities in the digital age are ever greater, wider, and more accessible. It is in such a changing context as this that a metamorphosis in learning can be produced [18] and which shapes the metaphor of learning ecologies as a perspective to analyze complex, dynamic, interconnected systems of creating, sharing, and acquiring knowledge [49,50].

Author Contributions: Conceptualization, J.-A.G.-M., E.-J.F.-A., and E.-R.R.-M.; formal analysis, J.-A.G.-M., E.-J.F.-A, and E.-R.R.-M.; methodology, J.-A.G.-M.; validation, J.-A.G.-M., E.-J.F.-A., and E.-R.R.-M. All authors equally contributed to write and review this article. All authors have read and agreed to the published version of the manuscript.

Funding: This article was produced within the research framework: "Ecologías de aprendizaje en la era digital: nuevas oportunidades para la formación del profesorado de educación secundaria" (Learning ecologies in the digital age: new opportunities for secondary education teacher training) (ECO4LEARN-SE), partially financed by the Ministry of Science, Innovation, and Universities (Reference RTI2018-095690-B-I00).

Institutional Review Board Statement: Not applicable.

Informed Consent Statement: Not applicable.

Conflicts of Interest: The authors declare no conflict of interest.

\section{References}

1. Becker, S.A.; Cummins, M.; Davis, A.; Freeman, A.; Hall, C.G.; Ananthanarayanan, V. NMC Horizon Report: 2017 Higher Education Edition; The New Media Consortium: Austin, TX, USA, 2017.

2. Zhu, M.; Bonk, C.J.; Doo, M.Y. Self-directed learning in MOOCs: Exploring the relationships among motivation, self-monitoring, and self-management. Educ. Technol. Res. Dev. 2020, 68, 2073-2093. [CrossRef]

3. Aoki, K. Technologies for Lifelong and Lifewide Learning and Recognition: A Vision for the Future. In Emerging Technologies and Pedagogies in the Curriculum; Yu, S., Ally, M., Tsinakos, A., Eds.; Springer: Singapore, 2020; pp. 41-52.

4. Brown, A.J.; Snower, D.J. Skills Development: Rethinking the Future. In Organisation for Economic Cooperation and Development; OECD Observer: Paris, France, 2012; Volume 290, p. 47. Available online: http:/ / bit.ly/2WXldi5 (accessed on 14 October 2020).

5. Assinnato, G.; Sanz, C.; Gorga, G.; Martin, M.V. Actitudes y percepciones de docentes y estudiantes en relación a las TIC. Revisión de la literatura. Rev. Iberoam. Tecnol. Educ. Educ. Tecnol. 2018, 22, 7-17. [CrossRef]

6. Martínez, J.A.G.; González-Sanmamed, M. Personal Learning Environments of Costa Rican Education Students: Analysis of Information Search Tools. Rev. Investig. Educ. 2017, 35, 389-407. [CrossRef]

7. Kompen, R.T.; Edirisingha, P.; Canaleta, X.; Alsina, M.; Monguet, J.M. Personal learning Environments based on Web 2.0 services in higher education. Telemat. Inform. 2019, 38, 194-206. [CrossRef]

8. Abdelrahman, M.; AbdelAlmuniem, A.; Almabhouh, A. The Current Use of Web 2.0 Tools in University Teaching from the Perspective of Faculty Members at the College of Educatio. Int. J. Instr. 2016, 9, 179-194.

9. Martínez, J.A.G.; González-Sanmamed, M. How do Costa Rican education students generate and manage content: A contribution to the study of their personal learn-ing environment. Digit. Educ. Rev. 2019, 36, 15-35. [CrossRef]

10. Castañeda, L.; Adell, J. Entornos Personales de Aprendizaje: Claves Para el Ecosistema Educativo en Red; Marfil: Alcoy, Spain, 2013.

11. Wu, J.; Hsiao, Y.-C.; Nian, M.-W. Using supervised machine learning on large-scale online forums to classify course-related Facebook messages in predicting learning achievement within the personal learning environment. Interact. Learn. Environ. 2020, 28, 65-80. [CrossRef]

12. Blok, M.; Van Ingen, E.; De Boer, A.H.; Slootman, M. The use of information and communication technologies by older people with cognitive impairments: From barriers to benefits. Comput. Hum. Behav. 2020, 104, 106173. [CrossRef]

13. Khan, M.L.; Welser, H.T.; Cisneros, C.; Manatong, G.; Idris, I.K. Digital inequality in the Appalachian Ohio: Understanding how demographics, internet access, and skills can shape vital information use (VIU). Telemat. Inform. 2020, 50, 101380. [CrossRef]

14. Torres, R.; Costa, C. Formación continua, aprendizaje a lo largo de la vida y PLEs. In Entornos Personales de Aprendizaje: Claves Para el Ecosistema Educativo en Red; Castañeda, L., Adell, J., Eds.; Marfil: Alcoy, Spain, 2020; pp. 85-92.

15. Durán, B.Z.; López, J.F.B.; Martínez, J.G.; Flores, T.G. Teaching training in ICT and digital competences in Higher Education System. Apertura 2017, 9, 80-96. [CrossRef]

16. Meerza, A.H.; Beauchamp, G. Factors influencing attitudes towards information and communication technology (ICT) amongst undergraduates: An empirical study conducted in Kuwait higher education institutions (KHEIs). Turk. Online J. Educ. Technol. 2017, 16, 35-42. Available online: http:/ / www.tojet.net/articles/v16i2/1624.pdf (accessed on 16 October 2020).

17. Drossel, K.; Eickelmann, B.; Gerick, J. Predictors of teachers' use of ICT in school—the relevance of school characteristics, teachers' attitudes and teacher collaboration. Educ. Inf. Technol. 2017, 22, 551-573. [CrossRef]

18. Gonzalez-Sanmamed, M.; Sangrà, A.; Souto-Seijo, A.; Blanco, I.E. Ecologías de aprendizaje en la era digital: Desafíos para la educación superior. Publicaciones 2020, 50, 83-102. [CrossRef]

19. Siemens, G. Connectivism: A learning theory for the digital age. Int. J. Instr. Technol. Distance Learn. 2005, 2, 1-9. 
20. Srijamdee, K.; Pholphirul, P. Does ICT familiarity always help promote educational outcomes? Empirical evidence from PISA-Thailand. Educ. Inf. Technol. 2020, 25, 2933-2970. [CrossRef]

21. González-Sanmamed, M.; Sangrà, A.; Muñoz-Carril, P.-C. We can, we know how. But do we want to? Teaching attitudes towards ICT based on the level of technology integration in schools. Technol. Pedagog. Educ. 2017, 26, 633-647. [CrossRef]

22. Tejedor-Tejedor, F.J.; García-Valcárcel-Muñoz-Repiso, A.; Prada-San-Segundo, S. A scale for the measurement of University teachers' attitudes towards the integration of ICT. Comunicar 2009, 17, 115-124. [CrossRef]

23. Ngo, H.; Eichelberger, A. College students' attitudes toward ICT use for English learning. Int. J. Educ. Dev. Using ICT 2019, 15, 31-40. Available online: https://www.learntechlib.org/p/209743/ (accessed on 16 October 2020).

24. Guillén-Gámez, F.D.; Mayorga-Fernández, M.J. Identification of Variables that Predict Teachers' Attitudes toward ICT in Higher Education for Teaching and Research: A Study with Regression. Sustainability 2020, 12, 1312. [CrossRef]

25. Martínez, J.A.G.; González-Sanmamed, M. La comunicación y la interacción como aspectos clave de los entornos personales de aprendizaje: Perspectiva de estudiantes costarricenses de educación. Rev. Electrón. Educ. 2020, 24, 1-20. [CrossRef]

26. Cheung, R.; Vogel, D. Can Facebook Enhance the Communications between Teachers and Students? Int. J. Learn. Annu. Rev. 2011, 17, 385-398. [CrossRef]

27. Davis, F.D. Perceived Usefulness, Perceived Ease of Use, and User Acceptance of Information Technology. MIS Q. 1989, 13, 319-340. [CrossRef]

28. Muñoz-Carril, P.-C.; González-Sanmamed, M.; Fuentes-Abeledo, E.-J. Use of blogs for prospective early childhood teachers. Educ. XX1 2019, 23, 247-273. [CrossRef]

29. Cabero-Almenara, J.; Pérez, J.L. TAM Model Validation Adoption of Augmented Reality through Structural Equations. Estud. Sobre Educ. 2018, 34, 129-153. [CrossRef]

30. Mondal, S.; Mishra, J. Students Attitude towards ICT in Teaching Learning Process in Higher Education. Purakala J. 2020, 31, 288-294.

31. Boateng, R.; Boateng, S.L.; Awuah, R.B.; Ansong, E.; Anderson, A.B. Videos in learning in higher education: Assessing perceptions and attitudes of students at the University of Ghana. Smart Learn. Environ. 2016, 3, 8. [CrossRef]

32. Wu, Y.-C.; Pan, C.-I.; Yuan, C.-H. Attitudes towards the use of information and communication technology in management education. Behav. Inf. Technol. 2016, 36, 243-254. [CrossRef]

33. Casillas-Martín, S.; Cabezas-González, M.; García-Peñalvo, F. Digital competence of early childhood education teachers: Attitude, knowledge and use of ICT. Eur. J. Teach. Educ. 2019, 43, 210-223. [CrossRef]

34. Martínez, J.A.G.; Rosa-Napal, F.-C.; Romero-Tabeayo, I.; López-Calvo, S.; Fuentes-Abeledo, E.-J. Digital Tools and Personal Learning Environments: An Analysis in Higher Education. Sustainability 2020, 12, 8180. [CrossRef]

35. Prendes-Espinosa, M.P.; Castañeda-Quintero, L.; Gutiérrez-Porlán, I. ICT competences of future teachers. Comunicar 2010, 18, 175-182. [CrossRef]

36. Mikropoulos, T.A. Research on E-Learning and ICT in Education: Technological, Pedagogical and Instructional Perspectives; Springer: Berlin/Heidelberg, Germany, 2018.

37. Benítez, L.M.; Sevillano, M.L.; Vásquez, E. Effects on academic performance in secondary students according to the use of ICT. IJERI 2019, 12, 90-108.

38. Fiedler, S.H.D.; Väljataga, T. Modeling the personal adult learner: The concept of PLE re-interpreted. Interact. Learn. Environ. 2020, 28, 658-670. [CrossRef]

39. Demirel, M.; Akkoyunlu, B. Prospective Teachers' Lifelong Learning Tendencies and Information Literacy Self-Efficacy. Educ. Res. Rev. 2017, 12, 329-337.

40. Seijas, E.J.; Val, J.C.; Cadavid, M.A.M.; Antelo, B.G. La formación del profesorado universitario en competencias lifelong learning a partir de las demandas de empleadores y egresados. Rev. Investig. Educ. 2015, 34, 69. [CrossRef]

41. Hu, X.; Gong, Y.; Lai, C.; Leung, F.K.S. The relationship between ICT and student literacy in mathematics, reading, and science across 44 countries: A multilevel analysis. Comput. Educ. 2018, 125, 1-13. [CrossRef]

42. Guillén-Gámez, F.D.; De Almería, E.U.; Martínez, S.J.R.; Camacho, X.G.O. Diagnosis of the attitudes towards ICT of education students according to gender and educational modality. Apertura 2020, 12. [CrossRef]

43. Alam, K.; Halder, U.K. Attitude towards the use of ICT in classroom among trainee-teachers. J. Educ. Dev. 2017, 7, $249-257$.

44. Programa Estado de la Nación. Estado de la educación costarricense. In Séptimo Informe Estado de la Educación; Masterlitho: San José, CA, USA, 2019.

45. Hernández, R.; Fernández, C.; Baptista, P. Metodología de la Investigación, 2nd ed.; Editorial Mc Graw Hill: Mexico City, Mexico, 2014.

46. Arnal, J.; Del Rincón, D.; Latorre, A. Investigación Educativa: Fundamentos y Metodología; Labor: Barcelona, Spain, 1992.

47. Mc Millan, J.H.; Schumacher, S. Investigación educativa. In Una Introducción Conceptual; Editorial Pearson Educación: Madrid, España, 2005.

48. Tabachnick, B.G.; Fidell, L.S. Using Multivariate Statistics, 4th ed.; HarperCollins: New York, NY, USA, 2001.

49. González-Sanmamed, M.; Muñoz-Carril, P.-C.; Santos-Caamaño, F. Key components of learning ecologies: A Delphi assessment. Br. J. Educ. Technol. 2019, 50, 1639-1655. [CrossRef]

50. González-Sanmamed, M.; Estévez, I.; Souto-Seijo, A.; Muñoz-Carril, P.-C. Digital learning ecologies and professional development of university professors. Comunicar 2020, 28, 9-18. [CrossRef] 